\title{
Analisa Transaksi Spot, Forward dan Swap Sebagai Alat Pengendalian Risiko
}

\author{
Siti Nur Asiah dan Harry Roestiono \\ Program Studi Manajemen, Sekolah Tinggi Ilmu Ekonomi Kesatuan \\ Bogor, Indonesia
}

E-Mail: snurasiah49@gmail.com

\begin{abstract}
Risk control is an important step and determines overall risk management. The known risks and their potential consequences must be managed appropriately, effectively, and accordingly company. Risk control is also necessary when foreign exchange transactions are due to currency fluctuations and foreign exchange differences. The exchange rate difference can be obtained from spot, forward and swap transactions we get from spot, forward and swap transactions. The purpose of this research is as follows: 1. To know the procedure of Spot, Forward and Swap foreign exchange transaction at $X$ bank,2. To know the risk control in foreign currency transactions at $X$ bank, 3. To know the analysis of spot, forward and swap transactions as risk control tools at $X$ bank. The research method used in this research is Research Methods Quantitative Descriptive Analysis. With this method facilitate the author in analyzing data from the results described by the author. The results show: spot transactions, certainly will avoid the risk of exchange rate fluctuations because the bank will directly benefit from the spot transactions. And using forward and swap transactions must still be done because to avoid the risk of unexpected exchange rate fluctuations, although there are some larger transactions than forward and swap contracts but negotiations can be done together.
\end{abstract}

Keywords: spot, forward, swap, risk control

\section{PENDAHULUAN}

Perbankan berdasarkan Undang-Undang Republik Indonesia Nomor 10 Tahun 1998, bank adalah badan usaha yang menghimpun dana dari masyarakat dalam bentuk simpanan dan menyalurkannya kepada masyarakat dalam bentuk kredit dan atau bentuk-bentuk lainnya dalam rangka meningkatkan taraf hidup rakyat banyak. Dapat disimpulkan bahwa bank ialah badan usaha milik negara maupun swasta yang memiliki fungsi dan tugas perbankan untuk menghimpun serta menyalurkan dana ke masyarakat dan melakukan kegiatan lain yang berhubungan dengan keuangan.

Sistem perbankan di Indonesia menganut asas demokrasi ekonomi. Maksudnya ialah perbankan menjalankan tugasnya dengan prinsip adil serta penuh kehati-hatian. Sementara itu, tujuan dari perbankan itu sendiri adalah menunjang pelaksanaan perekonomian di Indonesia, menunjang pembangunan nasional dan meningkatkan pemerataan pembangunan, serta mengawasi pertumbuhan ekonomi dan stabilitas nasional demi kesejahteraan hajat hidup orang banyak. Dalam dunia perbankan, kita sering kali mendengar ataupun membaca istilah valuta asing. bagi para pelaku yang berkecimpung di dunianya tentunya istilah valuta asing sudah tidak asing lagi. Valuta asing yang banyak dipakai biasanya merupakan mata uang suatu negara yang memiliki peranan ataupun kendali yang cukup besar dalam sistem perekonomian di seluruh dunia.

Bank sebagai lembaga intermediasi harus siap memfasilitasi setiap transaksi yang menggunakan tidak hanya dengan satu jenis mata uang, tetapi juga menggunakan
Submitted: NOVEMBER 2018

Accepted: DESEMBER 2018

\section{JIMKES}

Jurnal Ilmiah Manajemen Kesatuan Vol. 6 No. 3, 2018 pp. 139-146 STIE Kesatuan
ISSN $2337-7860$ 
Risk

Controlling

140

valuta asing. Namun, penggunaan valuta asing dalam transaksi memiliki risiko tersendiri yang harus diatasi oleh suatu bank. Bank yang melakukan transaksi dengan mata uang asing dituntut untuk menentukan strategi finansial yang harus dijalankan untuk meminimalkan risiko kerugian atas transaksi valasnya.

Transaksi tersebut berkaitan dengan nilai tukar mata uang. Maka bank harus memperhitungkan nilai tukar di masa yang akan datang di mana nilai tukar ditentukan oleh inflasi dan tingkat bunga. Hal yang harus diperhatikan oleh bank yang sering kali bertransaksi dengan berhubungan dengan nilai tukar dan suku bunga. Pengendalian risiko merupakan langkah penting dan menentukan keseluruhan manajemen risiko. Risiko yang telah diketahui besar dan potensi akibatnya harus dikelola dengan tepat, efektif, dan sesuai dengan kemampuan perusahaan. Sebagai perusahaan jasa, tujuan utama bank devisa jelas adalah untuk memberikan layanan terbaik kepada nasabahnya. Bentuk-bentuk pelayanan bank devisa diantaranya adalah menyediakan informasi tentang harga beberapa mata uang,menerima jasa penukaran (jual-beli) mata uang secara spot, forward maupun swap, menyediakan deposito bersatuan mata uang asing, memberikan kredit bersatuan mata uang asing, memfasilitasi perdagangan internasional, dan lain sebagainya.

Transaksi (jual-beli) mata uang secara dengan forward adalah transaksi yang terjadi dalam pasar valuta asing dengan penyerahannya dilakukan pada tanggal tertentu setelah tanggal kontrak yang bersangkutan. Transaksi spot adalah transaksi yang terjadi dalampasar valuta asing dengan penyerahan dalam dua hari kerja setelah tanggal terjadinya transaksi. Transaksi Swap merupakan transaksi dimana dua valuta asing ditukarkan melalui pembelian atau penjualan secara spot dan penjualan atau pembelian kembali secara forward. Dalam transaksi valas antara bank dengan nasabahnya seperti transaksi tunai (spot transaction), transaksi berjangka (forward transaction), dan swap transaksi. Pelaksanaan transaksi-transaksi tersebut sering terjadi resiko gejolak fluktuasi nilai tukar. Maka dari itu harus diterapkannya pengendalian risiko itu untuk meminimalisir risiko yang akan dihadapi.

Rumusan Masalah penelitian ini adalah : Bagaimana prosedur transaksi Spot, Forward dan Swap pada Bank X (Persero) Tbk?, Bagaimana pengendalian resiko dalam transaksi valas pada Bank X (Persero) Tbk? Dan Bagaimana analisis transaksi Spot, Forward dan Swap sebagi alat pengendalian resiko pada Bank X (Persero) Tbk?

\section{TINJAUAN PUSTAKA}

\section{Transaksi Jual Beli Spot}

Menurut Veitzhal Rival dkk $(2013,158)$ Transaksi SPOT, yaitu transaksi valuta asing yang penyerahannya efektif setelah dua hari kerja dengan nilai tukar yang telah disepakati sebelumya. Menurut Mamduh $(2016,137)$ Transaksi Spot merupakan transaksi valuta asing dengan penyerahan (delivery) saat itu juga (secara teoritis, meskipun dalam praktek transaksi spot diselesaikan dalam waktu dau atau tiga hari). Rumus selisih kurs untuk transaksi spot yaitu:

Transaksi Spot terdiri dari :

$$
\text { Selisih Kurs }=\frac{\text { Kurs Beli }}{\text { Kurs Jual-Kurs Tengah }}
$$

1. Today, adalah transaksi pembelian atau penjualan valuta asing misal (USD) terhadap valuta domestik (Rp) atau terhadap valuta asing lainnya berdasarkan nilai kurs hari ini, dengan penyerahan hari ini juga.

2. Tomorrow, adalah transaksi pembelian atau penjualan valuta asing misal (USD) terhadap valuta domestik $(\mathrm{Rp})$ atau terhadap valuta asing lainnya berdasarkan nilai kurs hari ini, dengan penyerahan 1 hari kerja setelah tanggal transaksi.

3. Spot, adalah transaksi pembelian atau penjualan valuta asing misal (USD) terhadap valuta domestik $(\mathrm{Rp})$ atau terhadap valuta asing lainnya berdasarkan nilai kurs hari ini, dengan penyerahan 2 hari kerja setelah tanggal transaksi. 
Menurut pendapat diatas transaksi spot dapat disimpulkan transaksi yang akan terhindar dari risiko karena penyerahan atau transaksi dilakukan pada hari yang sama ada dua hari kerja setelah tanggal transaksi. Beberapa transaksi bisa diselesaikan dalam waktu satu hari (misal antara US\$ dengan Canada \$).

\section{Transaksi Jual Beli Forward}

Menurut Veitzhal Rival dkk $(2013,158)$ Transaksi Forward adalah "transaksi valuta asing yang penyerahnnya efektif lebih dari dua hari kerja dengan nilai yang disepakati sebelumnya". Menurut Hamduh $(2016,138)$ Transaksi Forward dalam valuta asing merupakan "transaksi dengan penyerahan pada beberapa waktu mendatang sejumlah mata uang tertentu berdasarkan sejumlah mata uang tertentu yang lain".

Rumus Forward Rate $=S R+\frac{S R X(B-A) X T}{100 X D B}$

SR = Spot Rate

$\mathrm{B}-\mathrm{A}=$ Interest Differential

$\mathrm{T}=$ Periode

$\mathrm{DB}=$ Day basis of the year

\section{Transaksi Jual Beli Swap}

Menurut Veitzhal Rival dkk $(2013,158)$ Transaksi Swap adalah "transaksii valuta asing yang simultan antara transaksi spot (beli) dengan transaksi forward (jual) atau sebaliknya, biasanya dilakukan untuk menjaga posisi valuta asing sementara waktu dengan biaya tertentu". Menurut Hamduh $(2016,139)$ Transaksi swap merupakan "transaksi pembelian dan penjualan sejumlah mata uang tertentu secara simultan pada dua tanggal (value date) tertentu. Kedua transaksi tersebut dilakukan dengan bank lain yang sama". Menurut serfianto dkk $(2013,130)$ transaksi swap (transaksi barter) adalah kontrak kombinasi antara pembeli dan penjual untuk dua mata uang secara tunai yang diikuti dengan membeli dan menjual kembali mata uang yang sama secara tunai (spot) dan tunggak (forward) secara simultan dengan batas waktu yang berbeda.

Jenis Jenis Transaksi SWAP Menurut serfianto dkk $(2013,163)$ :

1. Transaksi Swap Suku Bunga (Interest Rate Swap), adalah suatu perjanjian antara dua pihak untuk melakukan pertukaran pembayaran bunga (rate). Berdasarkan kontrak tersebut, yang dipertukarkan adalah bunga (rate) dari suatu nominal dana di mana satu pihak menerima bunga tetap (fixed-rate) dan membayar bunga tidak tetap (floating-rate) sedangkan pihak lain menerima bunga tidak tetap (floating-rate) dan membayar bunga tetap (fixed-rate) untuk beberapa periode di masa mendatang. Menurut Hady Hamdy (2006) interest rate swap adalah "currency swap dari sejumlah mata uang atau valas yang sama, tetapi yang satu dengan tingkat bunga mengambang (floating)"

2. Transaksi Swap Mata Uang (Currency swap), adalah kontrak antara 2 pihak yang melibatkan pertukaran dana dalam mata uang A beserta bunganya dari pihak I dan dana dalam mata uang B beserta bunganya dari pihak II. Jika dalam interest rate swaps tidak terjadi perpindahan dana nominal, dalam currency swaps terjadi perpindahan dana nominal pada awal dan akhir kontrak.

\section{Pengendalian Resiko}

$$
\text { Swap Point }=\frac{\text { SR } \times\left(\text { F.C } \frac{I}{R}-R \cdot C \frac{I}{R}\right) \times \mathrm{D}}{360}
$$

Menurut Mulyawan $(2015,131)$ pengendalian risiko merupakan "langkah penting dan menentukan keseluruhan manajemen risiko. Risiko yang telah diketahui besar dan potensi akibatnya harus dikelola dengan tepat, efektif, dan sesuai dengan kemampuan perusahaan".

1. Pengendalian Risiko Pasar Banking Book

Menurut Mulyawan $(2015 ; 130)$ Bank tidak dapat mengatur pergerakan factor pasar. Yang dapat dilakukan adalah mengatur strategi posisi neraca, agar perubahan factor pasar memberikan keuntungan bagi bank, atau paling tidak meminimalisir potensi kerugian bank

2. Mengukur Dampak Perubahan Faktor Pasar Pada Neraca Bank 
Risk Controlling

Untuk mengetahui dampak perubahaan factor pasar pada posisi neraca, bank menggunakan tools yang disebut dengan analisa gap meliputi repiring gap, duration gap, foreign exchange gap, dan liquidity gap.

Foreign Exchange gap digunakan untuk mengukur perubahan nilai tukar pada posisi valuta asing bank.

$$
L D R=\frac{\text { Total Loan }}{\text { Total Deposit }+ \text { Equity }} \times 100 \%
$$

\section{2}

\section{METODOLOGI PENELITIAN}

Dalam memecahkan suatu masalah yang ada pada suatu penelitian diperlukan penyelidikan yang hati-hati, teratur dan terus menerus. Sedangkan untuk mengetahui bagaimana seharusnya langkah-langkah penelitian dilakukan penulis menggunakan metode penelitian. Secara umum metode penelitian diartikan sebagai cara ilmiah untuk mendapatkan data dengan tujuan dan kegunaan tertentu Sugiyono (2004). Dalam proposal skripsi ini metode penelitian yang digunakan oleh penulis adalah metode deskriptif. Metode ini bertujuan untuk menjawab pertanyaan dari identifikasi masalah yang telah diuraikan sebelumnya serta memberikan gambaran mengenai Analisa Transaksi Spot, Forward dan Swap Sebagai Alat Pengendalian Risiko. Berdasarkan tujuan penelitian, untuk dapat menjawab permasalahan yang teridentifikasi, peneliti melakukan operasional variabel serta pengujian data sesuai dengan metode analisis untuk menghasilkan simpulan.

Metode Analisis yang digunakan oleh penulis untuk melihat transaksi spot,forward dan swap sebagai alat pengendalian risiko. Penulis menggunakan metode analisis deskriptif dalam hal ini adalah menguraikan identifikasi masalah (variabel-variabel) secara rinci dan sistematis dengan penekanan pada perbandingan antara hasil riset lapangan (Field research) dengan teori terkini dan relevan yang diperoleh dari hasil riset kepustakaan (library research) dengan demikian kuantitas dan kualitas teori kepustakaan, serta validitas data/informasi hasil riset lapangan menjadi sangat penting.

Fokus penelitian ini adalah data transaksi spot, forward dan swap, proses transaksi spot, forward dan swap dan data perubahan kurs setiap harinya. Dari data tersebut diolah dan dihitung dan akan terlihat seberapa besar dapat meminimalkan beban biaya untuk mengurangi resiko. Metode pengumpulan data dengan menggunakan observasi.

Teknik analisis data dalam penelitian ini ada beberapa tahapan, yaitu :

1. Menguraikan prosedur transaksi di PT Bank X (Persero) Tbk

2. Membandingkan keuntungan/kerugian

a. Melalui Transaksi Spot

Selisih Kurs $=\frac{\text { Kurs Beli }}{\text { Kurs Jual-Kurs Tengah }}$

b. Melalui Transaksi Forward

Forward Rate $=S R+\frac{S R X(B-A) X T}{100 \times D B}$

c. Melalui Transaksi Swap

Swap Point $=\frac{\text { SR } \times\left(\text { F.C } \frac{I}{R}-R \cdot C \frac{I}{R}\right) \times \mathrm{D}}{360}$

Transaksi Forward dan Swap dilihat dari selisih antara ketika melakukan transaksi forward dan swap dengan open position.

3. Mengambil kesimpulan dari data yang telah diolah dan dianalisa

\section{HASIL DAN PEMBAHASAN}

\section{Prosedur Transaksi Spot, Forward dan Swap Pada PT Bank X (Persero) Tbk}

Dalam Prosedur Transaksi Spot PT Bank X (Persero) Tbk melakukan transaksi penjuala dan pembelian yang biasa dilakukan dalam kegiayan pemberian jasa bank yaitu penjualan dan pembelian valuta asing. Transaksi spot yang dilakukan menggunakan rumus yang sama dengan tinjauan pustaka. Dimana nasabah melakukan 
pembelian pada waktu yang sama dengan penyerahan diwaktu yang sama pula. Transaksi spot di PT Bank X (Persero) Tbk memberikan hasil selisih kurs pada saat itu juga sesuai dengan ketentuan rumus dan dilakukan dengan pelaksanaan yang dilakukan oleh bank PT Bank X (Persero) Tbk. Transaksi Spot yang dilakukan oleh PT Bank X (Persero) Tbk secara keseluruhan yaitu dilakukan dengan nasabah pada hari yang sama disaat perjanjian dan penyerahannya. Dalam transaksi spot di PT Bank X (Persero) Tbk telah ditetapkan selisih kurs atau bisa disebut keuntungan yang merupakan selisih dari transaksi spot tersebut.

Dalam Prosedur Transaksi Forward PT Bank X (Persero) Tbk menggunakan forward rate dalam pelaksanaannya, prosedurnya yaitu sesuai dengan tinjauan pustaka yang ada dengan menggunakan forward rate. Prosedur yang dilakukan yaitu dengan menjalankan kesepakatan bersama antara Bank dengan Counterpartynya. Dengan nilai forward rate yang telah disepakati bersama. Transaksi Forward yang dilakukan oleh PT Bank X (Persero) Tbk secara keseluruhan yaitu dilakukan dengan counterpartynya dengan waktu 90 hari atau bisa dihitung dengan artian tiga bulan pengendalian risiko nya pun menggunakan forward rate yang telah ada di dalam data yang dilampirkan, transaksi forward dalam pengendalian risiko di PT Bank X (Persero) Tbk ini telah dilaksanakan atau dilakukan yang tujuannya untuk berjaga jaga atau meminimalisir risiko akibat terjadinya fluktuasi nilai tukar dimasa mendatang, forward yang dilakukan merupakan penjualan dan pembelian valuta asing dengan beberapa counterparty yang bersama sama memiliki tujuan untuk menghindari risiko nilai tukar.

Dalam prosedur transaksi swap, PT Bank X (Persero) Tbk menerapkan nilai yang sama ketika menggunakan transaksi swap buy atau swap sell, dan prosedurnya pun sesuai dengan kesepakatan dan menggunakan rumus swap point untuk harga yang akan dijalankan dalam kontrak swapnya. Dimana bank akan membeli atau menjual kembali valuta asing yang di transaksikan. Transaksi Swap yang dilakukan oleh PT Bank X (Persero) Tbk secara keseluruhan yaitu dilakukan dengan counterpartynya dengan waktu 30hari atau bisa dibilang satu bulan, swap point dalam Bank BRI sudah ditentukan diawal perjanjian dan tanggal jatuh temponya pun sesuai dengan kesepakatan bersama. Swap di PT Bank X (Persero) Tbk semata mata untuk pengendalian risiko atau meminimalisir dari fluktuasi nilai tukar. Swap di PT Bank X (Persero) Tbk nya pun dilakukan sesuai dengan kontraknya, dengan pembelian atau penjualan di waktu realisasi dengan jumlah yang disepakati dan akan di lakukan pembelian atau penjualan kembali di tanggal jatuh tempo yang telah ditetapkan dengan kurs yang telah ditetapkan untuk mneghindari risiko nilai tukar.

\section{Pengendalian Resiko Dalam Transaksi Valas}

Pengendalian risiko merupakan "langkah penting dan menentukan keseluruhan manajemen risiko. Risiko yang telah diketahui besar dan potensi akibatnya harus dikelola dengan tepat, efektif, dan sesuai dengan kemampuan perusahaan" Dalam kegiatannya PT Bank X (Persero) Tbk melakukan pengendalian risiko dengan cara melakukan transaksi valuta asing dengan telah mengetahui potensi risiko yang ada, karena risiko fluktuasi nilai tukar yang sewaktu waktu dapat berubah ubah maka PT Bank X (Persero) Tbk menggunakan transaksi spot, forward dan swap dengan tujuan untuk menghindari potensi risiko tersebut.

Penggunaan transaksi spot yang memberikan keuntungan yang langsung sedangkan forward dengan jumlah yang tidak pasti dan swap untuk semata mata melindungi dari fluktuasi kurs. Fluktuasi kurs yang sangat besar dari tahun 2017 sampai dengan 2018 yang dapat mempengaruhi transaksi valuta asing (lihat Gambar 1).

\section{Transaksi Spot, Forward dan Swap Sebagai Alat Pengendalian Risiko}

Setelah dilakukan penelitian maka telah diketahui aktivitas aktivitas dimana dalam spot terdapat selisih kurs dan dalam forward dan swap terdapat aktivitas yang beresiko dalam melakukan transaksi forward dan swap yang dilakukan dengan cara membandingkan kurs dan nilai pada saat transaksi dengan kurs spot dalam open position. Perbedaan yang begitu jelas memberikan pengaruh terhadap keuntungan dan 
Risk Controlling

144

kerugian yang akan diperoleh. Dari transaksi spot yang diperoleh yaitu keuntungan bagi bank, dari forward yang diperoleh ada keuntungan dan kerugian yang diperoleh bank, sedangkan swap bank memperoleh keamanan dari fluktuasi kurs dimasa mendatang.

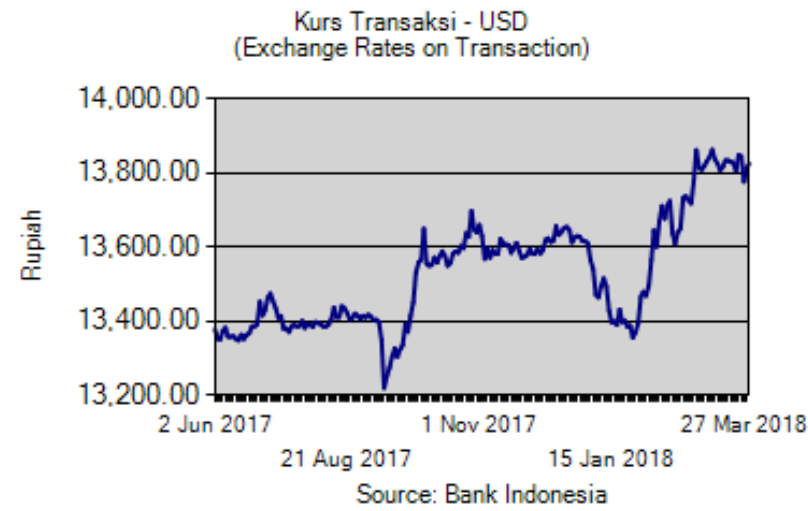

\section{Implikasi Penelitian}

Gambar 1 Kenaikan Kurs

Implikasi Penelitian disini akan disajikan dalam hasil dari setelah penggunaan transaksi spot, forward dan swap yang akan dilihat dari kerugian atau keuntungan setelah menggunakan transaksi spot, forward dan swap pada setelah melakukan transaksi penjualan dan pembelian valuta asing. Untuk transaksi forward dan swap nominal transaksi jual dan belinya sama. Dalam metode swap yang dilakukan adalah jual dan beli dilakukan secara bersama sama, yang satu secara spot dan yang satu secara forward.

Tabel 1. Analisis Kelayakan Penggunaan Transaksi Spot Pembelian dan Penjualan Valuta Asing

\begin{tabular}{llllr}
\hline \multicolumn{1}{c}{ Transaksi } & \multicolumn{2}{c}{ Nominal } & \multicolumn{2}{c}{ Keuntungan } \\
\hline Penjualan Valuta Asing & $\mathrm{Rp}$ & 80.055 .050 & $\mathrm{Rp}$ & 1.160 .218 \\
Pembelian Valuta Asing & $\mathrm{Rp}$ & 88.481 .250 & $\mathrm{Rp}$ & 1.269 .537 \\
Total & & & $\mathrm{Rp}$ & 2.429 .755 \\
\hline
\end{tabular}

Sumber : Data Sekunder Diolah

Dari tabel 1, dapat dilihat dengan menggunakan transaksi spot bank mendapatkan keuntungan yang jelas dan pasti, dari selisih kurs yang ada.

Tabel 2. Analisis Kelayakan Penggunaan Transaksi Forward Pembelian dan Penjualan

\begin{tabular}{lccc}
\hline \multicolumn{1}{c}{ Transaksi } & $\begin{array}{c}\text { Biaya Nominal dari } \\
\text { Hedging }\end{array}$ & Jumlah Tanpa Hedging & $\begin{array}{c}\text { Biaya Rill dari } \\
\text { Hedging }\end{array}$ \\
\hline Penjualan Valuta Asing & Rp25.937.487.200 & Rp 25.802.353.800 & Rp 135.133.400 \\
Pembelian Valuta & Rp25.965.419.200 & Rp 25.851.712.700 & Rp 113.706.500 \\
Asing & & & Rp 248.839.900 \\
Total & & &
\end{tabular}

Sumber : Data Sekunder diolah.

Dari tabel 2, nilai akumulasi dari penerapan penggunaan transaksi forward bank mendapatkan keuntungan dari transaksi penjualan valuta asing, sedangkan dengan pembelian valuta asing counterparty yang mendapatkan keuntungan dari penerapan transaksi forward. Maka bank berada dalam keadaan tidak pasti akibat fluktuasi nilai tukar valuta asing yang dapat menyebabkan bertambah besarnya nilai kewajiban apabila rupiah mengalami apresiasi terhadap dollar dan sebaliknya apabila rupiah mengalami apresiasi terhadap dollar bank mendapat keuntungan dari mengecilnya kewajiban. Hal ini terjadi karena PT Bank X (Persero) Tbk tidak menambil keputusan apapun untuk mengurangi risiko fluktuasi nilai tukar. 
Tabel 3. Analisis Kelayakan Penggunaan Transaksi Swap Pembelian dan Penjualan

\begin{tabular}{lccc}
\multicolumn{1}{c}{ Transaksi } & $\begin{array}{c}\text { Biaya Nominal dari } \\
\text { Hedging }\end{array}$ & Jumlah Tanpa Hedging & $\begin{array}{c}\text { Biaya Rill dari } \\
\text { Hedging }\end{array}$ \\
\hline $\begin{array}{l}\text { Penjualan Valuta Asing } \\
\text { Pembelian Valuta }\end{array}$ & Rp814.760.000.000 & Rp808.540.000.000 & Rp6.220.000.000 \\
Asing & Rp814.760.000.000 & Rp808.540.000.000 & Rp6.220.000.000 \\
\hline
\end{tabular}

Sumber : Data Sekunder diolah.

Dari tabel 3, dapat dilihat bahwa biaya rill dari hedging untuk kedua transaksi yang dilakukan bersama sama dalam waktu yang sudah ditentukan, yaitu untuk transaksi penjualan valuta asing hasilnya bernilai positif menunjukan bahwa ketika bank menggunakannya akan menguntungkan bagi bank, sedangkan untuk pembelian counterparty lah yang mengalami keuntungan karena selisih dari hedging dan tidak menggunakan hedging.

\section{PENUTUP}

Berdasarkan hasil pembahasan yang telah dipaparkan pada bab sebelumnya mengenai penelitian yang berjudul "Analisa Transaksi Spot, Forward dan Swap Sebagai Alat Pengendalian Risiko" maka penelitian ini menghasilkan kesimpulan, sebagai berikut:

a. Pada PT Bank X (Persero) Tbk Transaksi Spot, Forward dan Swap dilakukan dengan penetapan kurs pada tanggal perjanjian atau yang disebut deal date, kesepakatan tersebut dilakukan sesuai dengan keinginan bersama. Dari ketiga kegiatan tersebut dapat disimpulkan bahwa :

b. Transaksi Spot yang dilakukan pada maret 2018 memberikan keuntungan bagi bank, dan terhindar dari resiko fluktuasi kurs karena transaksi yang dilakukan direalisasi hari itu juga dan pada kurs yang berlaku pada saat itu juga.

c. Transaksi Forward yang dilakukan dari bulan juni 2018 sampai dengan maret 2018 dapat disimpulkan bahwa dengan menggunakan transaksi forward belum tentu akan mendapatkan keamanan dari fluktuasi kurs karena dari bulan juni sampai dengan maret kurs mengalami gejolak kenaikan yang sangat cukup besar yang apabila dikalikan dengan amount atau jumlah yang diinginkan dalam bertransaksi namun bebearapa transaksi yang dilakukan pada tanggal dan bulan tertentu dapat menghindari dari fluktuasi kurs dan akan mendapatkan keuntungan bagi kedua belah pihak.

d. Transaksi Swap yang dilakukan pada akhir november sampai dengan januari 2018 dengan jumlah yang sama dan tanggal pembelian dan penjualan yang sama bisa kita lihat bahwa dengan menggunakan transaksi swap lebih besar dari pada dalam keadaan open position, namun keuntungan yang didapatkan adalah sama bagi kedua belah pihak dan tidak ada kerugian karena dilakukan pada counterparty yang sama dengan kurs yang telah disepakati bersama.

e. Sehingga dapat disimpulkan bahwa dengan menggunakan transaksi spot, dapat dipastikan akan terhindar dari risiko fluktuasi kurs karena bank langsung akan mendapatkan keuntungan dari transaksi spot tersebut. Dan dengan menggunakan transaksi forward dan swap tetap harus dilakukan karena untuk menghindari risiko fluktuasi kurs yang tidak disangka sangka, meskipun ada beberapa transaksi yang lebih besar dari kontrak forward.

\section{DAFTAR PUSTAKA}

Fahmi, I., 2013. Manajemen resiko, Alfabeta, Bandung.

Fahmi, I., 2014. Bank dan lembaga keuangan lainnya, Alfabeta CV, Bandung.

Hanafi, M.M., 2016. Manajemen Keuangan Internasional. Edisi 3, Universitas Gadjah Mada, Yogyakarta.

Hull, J.C., 2006. Option, Future and Other Derivatives. Sixth Edition, Prentice Hall. 
Risk

Controlling

146
Ikatan Bankir Indonesia., dan Banker Association for Risk.2015. Management Manajemen Risiko 2, PT Gramedia pustaka utama, Jakarta.

Joesoef J.R. 2008. Pasar Uang Dang Pasar Valuta Asing, salemba Empat, Jakarta.

Kasmir, 2012. Bank dan Lembaga Keuangan Lainnya, PT RajaGrafindo Persada, Jakarta.

Madura, Jeff. 2009. Manajemen Keuangan Internasional, Buku 1 Edisi Delapan, Erlangga, Jakarta.

Martono., 2009. Bank Dan Lembaga Keuangan Lain, Ekonisia, Yogyakarta.

Mishkin, F.S., 2008. Ekonomi Uang perbankan, dan pasar keuangan,

Edisi 8, Salemba Empat, Jakarta.

Muchdarsyah, S., 2007. Manajemen Dana Bank, Rineka Cipta, Jakarta.

Mukhlis, I., 2015. Ekonomi Keuangan dan Perbankan, salemba empat, Jakarta.

Mulyawan, S., 2015. Manajemen Risiko, CV Pustaka Setia, Bandung.

Purnomo, D.S., Serfiyani, Y.C. dan Hariyani I., 2013. Pasar Uang dan Pasar Valas. PT Gramedia Pustaka Utama. Jakarta.

Rival, V., Sofyan, B. dan Sarwono S., 2013. Manajemen Perbankan, PT Rajagrafindo Persada, Jakarta.

Saragih,F.D., dan Yuliarto N. 2014. Dasar Dasar Keuangan Internasional, PT Rajagrafindo Persada, Jakarta.

Silviani, K., 2009. Bank dan lembaga keuangan lain. PT Gelora Aksara Pratama, Jakarta.

Sunaryo, T., 2009. Manajemen Risiko Financial, Salemba Empat, Jakarta.

Triyono., 2008. Analisis Perubahan Kurs Rupiah Terhadap Dollar Amerika. Jurnal Ekonomi Pembangunan. Vol.9 no.2, Desember 2008 : 156-167.

Wijayanta., dan Vidyaningsih, 2008. Mengasah Kemampuan Ekonomi, Citra Praya,

Thobarry, A. 2009. Analisis Pengaruh Nilai Tukar, suku bunga,laju inflasi, dan pertumbuhan GDP tehadap Indeks Harga saham sector Properties : Kasus di BEI Periode 2000-2008

Nourma, Y., 2011. Pengaruh Suku Bunga, Valuta Asing Terhadap Transaksi Ekspor Impor. 